\title{
Developing Operational Capabilities in the Collaborative Practice-Adoption Process through Different Triadic Structures
}

\author{
Eliciane Maria Silva ${ }^{1}$ \\ Ely Laureano Paiva ${ }^{2}$ \\ Mário Sacomano Neto ${ }^{3}$ \\ Kenyth Alves de Freitas ${ }^{2}$ \\ ${ }^{1}$ Universidade Metodista de Piracicaba, Piracicaba, SP, Brazil \\ ${ }^{2}$ Fundação Getúlio Vargas, EAESP, São Paulo, SP, Brazil \\ ${ }^{3}$ Universidade Federal de São Carlos, São Carlos, SP, Brazil
}

Received 07 March 2021. This paper was with the authors for one revision. Accepted 14 July 2021.

First published online 05 November 2021.

Editors-in-Chief: Carlo Gabriel Porto Bellini (D) (Universidade Federal da Paraiba, Brazil)

Ivan Lapuente Garrido (ID) (Universidade do Vale do Rio dos Sinos, Brazil)

Associate Editor: Rafael Teixeira (ID (College of Charleston, Charleston, South Carolina, USA)

Reviewers: Miriam Borchardt (ID (Universidade do Vale do Rio dos Sinos, São Leopoldo, RS, Brazil) and Simone Sehnem (ID) (Universidade do Oeste de Santa Catarina, Chapecó, SC, Brazil; Universidade do Sul de Santa Catarina, Florianópolis, SC, Brazil)

Editorial assistants: Kler Godoy and Simone Rafael (ANPAD, Maringá, PR, Brazil) 


\begin{abstract}
Our study investigates how collaboration from a triadic perspective affects the development of operational capabilities through a practice-adoption process. This research conducted a multiple case study in three triads in Brazil. The results imply that inter-organizational collaboration plays a positive role by moderating the relationship between information technology practices and the development of customization, responsiveness, and cooperation capabilities. Moreover, sharing information emerges as a critical factor for these three capabilities when collaboration is present. In addition, collaboration enables the development of improvement-thinking, dyadic-diffused relationships between buyer-supplier or supplier-supplier in an open triad. In this triadic structure, the first-tier supplier plays a unique role in information sharing and capabilities development. On the other hand, to ensure the development of other capabilities, such as responsiveness, the buyer and second-tier supplier must expand their connection to form at least a transitional structure.
\end{abstract}

Keywords: collaboration; operational capabilities; practice-adoption; supply chain management; triads; multiple case study

JEL Code: L6 


\section{INTRODUCTION}

The Operations and Supply Chain Management (OSCM) literature has shown a growing interest in studying triads in recent years (Demirel, MacCarthy, Ritterskamp, Champneys, \& Gross, 2019; Ta, Esper, \& Hofer, 2018; Wynstra, Spring, \& Schoenherr, 2015; Zhang, Lawrence, \& Anderson, 2015) and multi-tiers theories (Kannan, 2021). However, most OSCM studies have focused on the relational context of dyadic relationships in supply chains (Gong, Jia, Brown, \& Koh, 2018; Sauer \& Seuring, 2019; Wilhelm, Blome, Bhakoo, \& Paulraj, 2016). A dyad is a relationship that connected a buyer and a supplier. On the other hand, a triad consists of at least three nodes connected by two relationships, including several interactions involving buyers, suppliers, and end-users (Choi \& Wu, 2009). According to Choi and Wu (2009):

a dyad shows how a node affects another node, but it is not able to address how a link may affect another link ... the triad that captures the basic essence of a network and allows us to study the behavior of a network (Choi \& Wu, 2009, p. 263).

Therefore, understanding the process of capability development from a triadic perspective is essential for supply chain theory and practice (Demirel et al., 2019; Ta et al., 2018; Wynstra et al., 2015; Zhang et al., 2015).

Collective triadic relationships produce a superior performance to dyadic-diffused relationships since they can capture most benefits because of their greater bargaining power (Lanier, Wempe, \& Zacharia, 2010; Nimmy, Chilkapure, \& Pillai, 2019). However, triads are embedded in different structures, affecting how companies interact and collaborate (Ta et al., 2018; Wynstra et al., 2015; Zhang \& Cao, 2015). Mena, Humphries, and Choi (2013) distinct triads according to the relationships established for the buyer with the first- and second-tier suppliers. In other words, how the buyer can access and influence the second-tier supplier affects how they collaborate. Despite the importance of the triadic and multi-tier approach to understand supply chain performance (Demirel et al., 2019; Ta et al., 2018; Wynstra et al., 2015; Zhang et al., 2015), it remains uncharted how they interact to develop capabilities in a collaborative practice-adoption process (Nimmy et al., 2019).

Our research expands prior studies by focusing on understanding how the buyer-supplier-supplier collaborative practice-adoption process occurs in different triadic structures (Wu \& Choi, 2005). Therefore, this study was guided by the following question: "How do triadic structures influence the collaborative practice-adoption process and the development of operational capabilities in supply chains?" This research aims to understand how collaboration from a triadic perspective affects the development of operational capabilities through a practice-adoption process. To answer these questions, we conducted a multiple case study in three supply chain triads (Eisenhardt, 1989; Yin, 2014), analyzing buyer-supplier-supplier relationships in three industrial sectors in Brazil: the automotive, chemical, and electrical-electronic.

Thus, this study contributes to understanding the role of collaboration in developing operational capabilities in supply chains, particularly from a triadic perspective. The results indicate that collaboration makes room for capabilities development, such as customization, responsiveness,

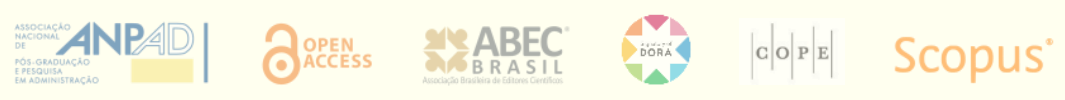


and cooperation capabilities. Moreover, we contribute to the OSCM literature by addressing how triadic structures affect the collaborative practice-adoption process and the development of operational capabilities (Mena et al., 2013).

Our findings suggest that in open triads, those in which the buyer has no direct connection to second-tier suppliers, the first-tier supplier has an essential role to play, diffusing information and knowledge throughout the entire triad. This 'middle-man' orchestrated the practice-adoption process in supply chains, developing need capabilities in its suppliers. However, it has limited action in some capabilities. On the other hand, in transactional and close triads, those in which the buyer reaches the second-tier supplier directly, the buyer established quality standards for the entire supply chain, sharing information and resources such as practices, tools, and equipment. Therefore, the buyer and the second-tier supplier should expand the triadic structure to at least a transitional triad to develop other capabilities, such as responsiveness.

The sequential order of this paper is as follows: Section 2 presents a literature review of practices and operational capabilities in the context of supply chain management. Section 3 describes the methodological approaches used based on a multiple case study. Section 4 gives the results of the analysis, while their discussion is found in Section 5. Finally, the main conclusions and suggestions for future studies are presented in the last section.

\section{THEORETICAL FRAMEWORK}

\section{Operational capabilities' development in a practice-adoption process}

Practices are internal and external activities that improve operational performance (Flynn, Sakakibara, \& Schroeder, 1995; Wu, Melnyk, \& Swink, 2012). With an internal focus, we can include practices such as just-in-time (JIT) (Flynn et al., 1995; Khalfallah \& Lakhal, 2020), total quality management (TQM) (Alsawafi, Lemke, \& Yang, 2021; Krause, Handfield, \& Scannell, 1998), IT-based practices (Frohlich \& Westbrook, 2001), and practices related to integrated product development (Tan, Kannan, \& Narasimhan, 2007; Zimmermann, Ferreira, \& Moreira, 2020). We can include integration practices adopted for buyers and suppliers with an external focus, such as quality management systems (QMS) and integrated product development (Bianchi \& Ferraz, 2020).

Past studies have analyzed the extent of the integration of operational practices between suppliers and client firms, particularly in dyads (Gong et al., 2018; Sauer \& Seuring, 2019; Wilhelm et al., 2016). In this study, we adopted the perspective of Krause, Handfield, and Scannell (1998). These authors argued that there is an evolutionary path to developing practices between buyer and supplier and two approaches to conducting them: the 'strategic approach' and the 'reactive approach.' In the former, cross-functional teams develop supply chain practices with "the intention to create a world-class supply base capable of providing a sustainable competitive advantage" (Krause et al., 1998, p. 45). Regarding the second approach, the practices are adopted merely to remedy or control the production process.

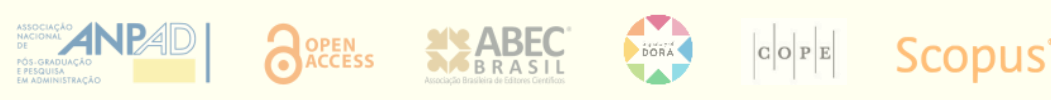


Operational practices lie at the root of capabilities. Implementing practices between firms provides a way of eliciting a firm's tacit knowledge embedded in its existing routines. This process then helps identify opportunities for improvement and select new routines (Bromiley \& Rau, 2014). According to Wu, Melnyk, and Swink (2012), the skills, processes, and specific routines developed in operational systems and used for solving problems by employing operational resources could be considered operational capabilities. In a broader conceptualization, organizational capabilities are firm-specific, developed internally, and difficult to imitate or transfer (Swink \& Hegarty, 1998). Capabilities provide both explicit elements (e.g., resources and practices) and tacit elements (e.g., know-how, skill sets, and leadership) (Saunila, Ukko, Rantala, Nasiri, \& Rantanen, 2020). Therefore, operational capabilities are part of an organization's capabilities.

Swink and Hegarty (1998) defined seven categories of operational capability. The studies of Wu, Melnyk, and Flynn (2010) and Wu et al. (2012) complemented the former by clarifying the understanding of six of these categories. Table 1 presents a synthesis of the definitions of the operational capabilities employed in manufacturing processes.

Table 1

\section{Definition and variables of operational capabilities}

\begin{tabular}{|c|c|}
\hline Definition & Variables \\
\hline $\begin{array}{l}\text { Operational improvement capabilities are specific abilities that } \\
\text { create an incremental improvement in operational routines } \\
\text { and processes. }\end{array}$ & $\begin{array}{l}\text { Continuously improve processes, reduce waste and variance, } \\
\text { and standardize and simplify production processes; an ability } \\
\text { to impel human resource. }\end{array}$ \\
\hline $\begin{array}{l}\text { Operational innovation capabilities are specific abilities that } \\
\text { create new products and process implementation. }\end{array}$ & $\begin{array}{l}\text { Change in technology trajectories, new methods, and ideas, } \\
\text { the introduction of new products. }\end{array}$ \\
\hline $\begin{array}{l}\text { Operational customization capabilities represent the ability to } \\
\text { know a buyer's requirement, learn and collect valuable } \\
\text { information, and develop proper processes. }\end{array}$ & $\begin{array}{l}\text { Cross-functional team, sharing information, the development } \\
\text { of know-how, use of technology in the proper way, and } \\
\text { customization process. }\end{array}$ \\
\hline $\begin{array}{l}\text { Operational control capabilities are abilities to direct and } \\
\text { regulate operating processes. }\end{array}$ & $\begin{array}{l}\text { Knowledge of process manufacturing limits, assessment, and } \\
\text { feedback of manufacturing process, ability to fit adverse } \\
\text { effects of operations. }\end{array}$ \\
\hline $\begin{array}{l}\text { Operational responsiveness capabilities are abilities to alter } \\
\text { the manufacturing process easily. }\end{array}$ & $\begin{array}{l}\text { Flexible volume, flexible mix, reduction in equipment } \\
\text { availability uncertainty by quickly and easily changing the } \\
\text { route, and adjusting for unexpected variations in components } \\
\text { and material inputs easily and quickly. }\end{array}$ \\
\hline $\begin{array}{l}\text { Operational cooperation capabilities can cooperate and } \\
\text { create a stable relationship with intra- and inter-cross- } \\
\text { functional teams. }\end{array}$ & $\begin{array}{l}\text { The ability for a quick diagnosis and the resolution of } \\
\text { problems, use of methods that motivate teamwork. }\end{array}$ \\
\hline $\begin{array}{l}\text { Process reconfiguration capabilities can re-establish and fit } \\
\text { operational strategies according to market and environmental } \\
\text { changes when unexpected interruptions occur. }\end{array}$ & $\begin{array}{l}\text { Sense/awareness of the change in the environment, adoption } \\
\text { of new and better practices to respond to market changes, } \\
\text { reconfiguration (combine or release) resources to respond to } \\
\text { market change, develop competence skills to respond to } \\
\text { market changes. }\end{array}$ \\
\hline
\end{tabular}

Note. Source: Adapted from Swink, M., \& Hegarty, W. H. (1998). Core manufacturing capabilities and their links to product differentiation. International Journal of Operations and Production Management, 18(4), 374-396. Wu, S. J., Melnyk, S. A., \& Flynn, B. B. (2010). Operational capabilities: the secret ingredient. Decision Sciences, 41(4), 721-754. Wu, S. J., Melnyk, S. A., \& Swink, M. (2012). An empirical investigation of the combinatorial nature of operational practices and operational capabilities: Compensatory or additive? International Journal of Operations and Production Management, 32(2), 121-155. 
Inter-organizational collaboration is strongly related to the development of capabilities. It can be expressed as ongoing participation by way of cross-functional teams (Monczka, Petersen, Handfield, \& Ragatz, 1998), goal congruence (Cao \& Zhang, 2011), a long-term partnership or commitment (Sheu, Yen, \& Chae, 2006), or knowledge transfer (Grant, 1996). This paper extends prior studies (Wu, Melnyk, \& Flynn (2010); Wu et al., 2012) by analyzing the development of operational capabilities based on inter-organizational collaboration and practices from a multi-tier supplier perspective.

\section{Inter-organizational collaboration}

A strong inter-organizational relationship with strategic partners can be a source of distinct value creation (Day, Fawcett, Fawcett, \& Magnan, 2013; Morgan \& Hunt, 1994). It can provide access to information, ideas, products, technologies, and process innovation (Dyer \& Singh, 1998; Madhok, 2002). According to Eltantawy, Paulraj, Giunipero, Naslund, and Thute (2015), the flow of information increases in collaborative relationships and can also reduce costs and improve quality.

Table 2

Constructs and dimensions of operational practices and inter-organizational collaboration in supply chains

\begin{tabular}{|c|c|c|}
\hline & Construct/Dimensions & Authors \\
\hline \multirow[t]{5}{*}{$\begin{array}{l}\text { Operational } \\
\text { practices }\end{array}$} & $\begin{array}{l}\text { Quality management practices } \\
\text { Lean Six Sigma, ISO/TS 16949, advanced } \\
\text { product quality planning (APQP), production part } \\
\text { approval process (PPAP), overall equipment } \\
\text { effectiveness (OEE) }\end{array}$ & $\begin{array}{l}\text { Escrig-Tena, Segarra-Ciprés, and García-Juan } \\
\text { (2021); Krause et al. (1998); Timans, Antony, Ahaus, } \\
\text { and Van Solingen (2012); Sroufe and Curkovic } \\
\text { (2008); Wu et al. (2012) }\end{array}$ \\
\hline & Information technologies practice & Fatorachian and Kazemi (2021); Frohlich and \\
\hline & $\begin{array}{l}\text { Continuous replenishment program to control } \\
\text { stocks (vendor managed inventory, VMI), } \\
\text { enterprise resource planning systems, semi- } \\
\text { automatic systems for joint production planning, } \\
\text { telephone, and e-mail }\end{array}$ & Westbrook (2001); Kotha and Swamidass (2000) \\
\hline & $\begin{array}{l}\text { JIT flow practices } \\
\text { Just-in-sequence, milk-run }\end{array}$ & $\begin{array}{l}\text { Amrani and Ducq (2020); Claycomb, Germain, and } \\
\text { Dröge (1999); Dong, Carter, and Dresner (2001); } \\
\text { Kaynak (2002) }\end{array}$ \\
\hline & $\begin{array}{l}\text { Integrated product development practice } \\
\text { Technical knowledge exchange }\end{array}$ & $\begin{array}{l}\text { Kotabe, Martin, and Domoto (2003); Prajogo, Mena, } \\
\text { and Chowdhury (2021); Zhang, Guo, Jiang, Wu, and } \\
\text { Jiang (2021) }\end{array}$ \\
\hline \multirow[t]{6}{*}{$\begin{array}{l}\text { Inter- } \\
\text { organizational } \\
\text { collaboration }\end{array}$} & Information sharing/Knowledge transfer & $\begin{array}{l}\text { Cao and Zhang (2011); Dyer and Nobeoka (2000); } \\
\text { Hardy, Phillips, and Lawrence (2003); Parente, } \\
\text { Murray, Zhao, Kotabe, and Dias (2020) }\end{array}$ \\
\hline & Inter/cross-functional teams & $\begin{array}{l}\text { Monczka, Petersen, Handfield, and Ragatz (1998); } \\
\text { Wagner and Bukó (2005) }\end{array}$ \\
\hline & Long term partnerships & $\begin{array}{l}\text { Cao and Zhang (2011); Ramanathan and } \\
\text { Gunasekaran (2014); Sheu, Yen, and Chae (2006) }\end{array}$ \\
\hline & $\begin{array}{l}\text { Goal congruence } \\
\text { Idea sharing, capacity planning, common } \\
\text { strategic goals, demand planning, cost planning }\end{array}$ & Cao and Zhang (2011); Zhang and Cao (2018) \\
\hline & Investments in proper tools and equipment & Hardy et al. (2003); Silveira and Arkader (2007) \\
\hline & Collaborative communication & $\begin{array}{l}\text { Cao and Zhang (2011); Liao, Hu, and Ding (2017); } \\
\text { Zhang and Cao (2018) }\end{array}$ \\
\hline
\end{tabular}


Few studies, however, have demonstrated the success achieved through collaboration and the attainment of distinct competitive advantages (Fawcett, McCarter, Fawcett, Webb, \& Magnan, 2015; Swanson, Jin, Fawcett, \& Fawcett, 2017). Previous studies have analyzed the effects of interfirm collaboration on different approaches, such as the development of new products, cost reduction (Braziotis, Tannock, \& Bourlakis, 2017), the firm's performance (Cao \& Zhang, 2011), and the effects of internal resources on level execution in the supply chain. Other studies explore the impact of supply chain collaboration on collaborative advantage and a firm's performance (Kotzab, Teller, Grant, \& Friis, 2015). Nevertheless, the moderating effects of inter-organizational collaboration on operational practices and capabilities remain unexplored. Table 2 presents a synthesis of the constructs and dimensions of operational practices and inter-organizational collaboration in the supply chain used as the basis for collecting the data in our empirical study.

Few researchers have attempted to understand collaboration from a triadic perspective (Nimmy et al., 2019). Mena, Humphries, and Choi (2013) proposed three multi-tier supply chain structures related to triadic relationships: open, transactional, and closed triads. An open triad means a traditional supply chain where information and product flows are linear, and there is no direct connection between the buyer and the supplier's supplier. The closed triad occurs when the buyer and the supplier's supplier have established a formal link and are directly connected. A transactional triad occurs when a buyer reaches out to a tier two supplier (for example, by providing training and direct sourcing) to build connections to become a closed triad.

According to Lanier, Wempe, and Zacharia (2010), companies in a triadic relationship can obtain more benefits than in a dyadic one. However, few studies investigate this relationship from a collaboration perspective. This paper extends prior studies by analyzing the role of collaboration in developing operational capabilities in a practice-adoption process from a triadic perspective (Gong et al., 2018; Mena et al., 2013; Nimmy et al., 2019). In addition, we contribute to the OSCM literature by addressing how triadic structures affect the collaborative practice-adoption process (Mena et al., 2013).

\section{RESEARCH METHODS}

We used the multiple case study in three supply chain triads (Eisenhardt, 1989; Yin, 2014) and collected data through in-depth interviews and observation. In this qualitative approach, we aim to understand how collaboration affects capabilities' development through the practice-adoption process from a triadic perspective. Two techniques for preparing the analyzed categories were employed: codification based on theoretical arguments taken from the previous literature and codification based on our interview transcripts.

We analyzed the operational capabilities arising from supply chain practices and the collaboration present in three industrial sectors in Brazil: the automotive, chemical, and electrical-electronic. The case study approach is an important research strategy for analyzing complex subjects and understanding the context behind them (Barratt, Choi, \& Li, 2011; Meredith, 1993).

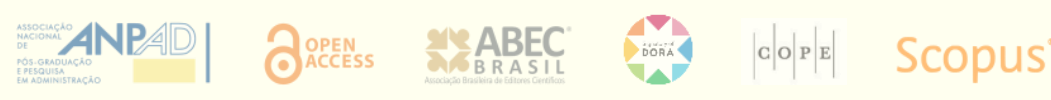


To ensure quality criteria and replication and improve internal and external validities (Yin, 2014), we designed this research following the five-stage model for case studies proposed by Eisenhardt (1989). Besides the research questions presented in this paper's introduction, the structure of the following subsections includes the four other steps: case selection, data gathering, data analysis, and replication.

\section{Case selection}

This study took place in the period during which Brazil was a significant player in the world economy. The BRIC (Brazil, Russia, India, and China) countries grew by more than $45 \%$ between the early 1990s and 2010, leading to a rapid increase in foreign direct investments and development financing ( International Monetary Fund [IMF], 2011). These developments created internal demand, which attracted new investment by many global players in industries such as consumer goods, high-tech, and electronics.

The supply chains selected for this study are related to multinational companies with plants in Brazil. After identifying the appropriate cases, managers were invited to participate by email and telephone. We analyzed the buyer-supplier-supplier triadic relationships in three supply chains, involving a total of 12 companies (Figures 1, 2, and 3). Table 3 presents demographic data on the firms that one of the researchers visited in this study.

\section{Data gathering}

We interviewed managers as our primary data source, performing most of the interviews from June 2012 to February 2013. Additionally, we carried out three more interviews to complete the triadic relationship in Case 3 from December 2018 to March 2019. We conducted 20 interviews in total, each lasting between 60 and 180 minutes, either in loco or by phone. According to Mena et al. (2013), the selected triads were considered open and transactional multi-tier supply chain structures (Figures 1, 2, and 3).

The within-case analysis technique was used in the case study (Eisenhardt, 1989). We used an interview protocol following Yin (2014), which was composed of open questions and the main concepts identified during the theoretical review (Table 4). The 20 interviews were transcribed, and the data were input using QSR NVIVO 10 software. 
Table 3

\section{Selected cases}

\begin{tabular}{|c|c|c|c|c|c|}
\hline Cas & /Firms & $\begin{array}{l}\text { Corporation data / foundation / } \\
\text { industrial sector }\end{array}$ & $\begin{array}{l}\text { Brazil location / } \\
\text { foundation / employee } \\
\text { numbers }\end{array}$ & Firms' description & $\begin{array}{l}\text { Relationship } \\
\text { time }\end{array}$ \\
\hline \multirow{5}{*}{ 嵌 } & OEM & German / 1933 / Automotive sector & $\begin{array}{l}\text { São Paulo State / } 1953 \text { / } \\
13.386\end{array}$ & Automobile manufacturer and assembler & \multirow{2}{*}{$\begin{array}{l}\text { OEM and T1a: } \\
7 \text { years }\end{array}$} \\
\hline & T1a & German / 1933 / Automotive sector & São Paulo State /1996 / & Manufacturer of different models ( 48 models) of engine for cars & \\
\hline & $\mathrm{T} 2 \mathrm{a}$ & $\begin{array}{l}\text { Michigan (USA) / } 1899 \text { / Automotive } \\
\text { industry }\end{array}$ & $\begin{array}{l}\text { São Paulo State / } 1899 \text { / } \\
542\end{array}$ & $\begin{array}{l}\text { Pistons, rings, pins, liners, valve seats and guides, ignition products, } \\
\text { bearings, bushings, heatshields, sealing products, transmission } \\
\text { components, brake and chassis components, and systems protection } \\
\text { products }\end{array}$ & $\begin{array}{l}\text { T1a-T2a: } 7 \\
\text { years }\end{array}$ \\
\hline & $\mathrm{T} 1 \mathrm{~b}$ & $\begin{array}{l}\text { Corbetta (Italy) / } 1919 \text { / Automotive } \\
\text { industry }\end{array}$ & $\begin{array}{l}\text { São Paulo State / } 1978 \text { / } \\
9.702\end{array}$ & $\begin{array}{l}\text { Development and manufacturing of systems, modules, and high- } \\
\text { technology components for the automotive industry }\end{array}$ & $\begin{array}{l}\text { OEM and } T 1 b \text { : } \\
20 \text { years }\end{array}$ \\
\hline & $\mathrm{T} 2 \mathrm{~b}$ & $\begin{array}{l}\text { São Paulo (Brazil) / } 1963 \text { / Automotive } \\
\text { industry }\end{array}$ & $\begin{array}{l}\text { São Paulo State / } 1963 \text { / } \\
354\end{array}$ & $\begin{array}{l}\text { It specializes in gravity and low pressure die casting and machined parts in } \\
\text { aluminum alloys (air intake manifold, transmission housing/flywheel } \\
\text { housing, oil pan, brackets for heavy vehicles, among others) }\end{array}$ & $\begin{array}{l}\mathrm{T} 1 \mathrm{~b} \text { and } \mathrm{T} 2: 13 \\
\text { years }\end{array}$ \\
\hline \multirow{4}{*}{ 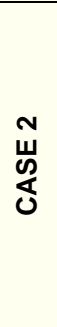 } & OEM & Illinois (USA) / 1925 / Heavy equipment & $\begin{array}{l}\text { São Paulo State / } 1954 \text { / } \\
16.441\end{array}$ & $\begin{array}{l}\text { Manufacturer of construction and mining equipment, diesel and natural gas } \\
\text { engines, industrial gas turbines, and diesel-electric locomotives } \\
\text { Distributor of packaging and tags for identification, prints and tools for }\end{array}$ & $\begin{array}{l}\text { OEM and } \mathrm{T} 1: \\
16 \text { years }\end{array}$ \\
\hline & Distributor & São Paulo (Brazil) / 1979 & $\begin{array}{l}\text { São Paulo State / } 1979 \text { / } \\
45\end{array}$ & $\begin{array}{l}\text { identification, sandpaper, abrasive discs, tools for welding and painting, } \\
\text { electrical OEM taps, flexible insulation, abrasives brushes, abrasive } \\
\text { accessories }\end{array}$ & $\begin{array}{l}\text { Distributor and } \\
\text { T1: } 32 \text { years }\end{array}$ \\
\hline & $\mathrm{T} 1$ & $\begin{array}{l}\text { Minnesota (USA) / } 1902 \text { / Chemical } \\
\text { industry }\end{array}$ & $\begin{array}{l}\text { São Paulo State / } 1946 \text { / } \\
3.262\end{array}$ & $\begin{array}{l}\text { With } 35 \text { business units, distributed among the groups: consumer, } \\
\text { electronics and energy, health care, industrial, safety and graphics }\end{array}$ & $\begin{array}{l}\mathrm{T} 1 \text { and } \mathrm{T} 235 \\
\text { years }\end{array}$ \\
\hline & T2 & São Paulo (Brazil) / Chemical industry & $\begin{array}{l}\text { São Paulo State / } 1961 / \\
784\end{array}$ & $\begin{array}{l}\text { A mineral transformation industry, processing bauxite, electrofusion, } \\
\text { generating aluminum oxide }\end{array}$ & \\
\hline \multirow{3}{*}{ 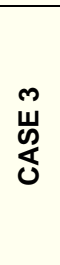 } & OEM & $\begin{array}{l}\text { Illinois (USA) / 1928 / } \\
\text { Telecommunications }\end{array}$ & $\begin{array}{l}\text { São Paulo State / } 1971 / \\
6.240\end{array}$ & $\begin{array}{l}\text { Tablet computers, mobile phones, smartphones, two-way radios, } \\
\text { networking systems, cable television systems, wireless broadband } \\
\text { networks, RFID systems, mobile telephone infrastructure }\end{array}$ & $\begin{array}{l}\text { OEM-C3 and } \\
\text { T1-C3: } 7 \text { years }\end{array}$ \\
\hline & $\mathrm{T} 1$ & $\begin{array}{l}\text { California (USA) / Electronics } \\
\text { manufacturing services and } \\
\text { manufacturer of backplanes }\end{array}$ & $\begin{array}{l}\text { São Paulo State / } 1996 \text { / } \\
865\end{array}$ & Electronics manufacturing services (contract manufacturer) & \\
\hline & T2 & $\begin{array}{l}\text { São Paulo (Brazil) / Logistics and } \\
\text { packaging sector }\end{array}$ & $\begin{array}{l}\text { São Paulo State / } 1998 \text { / } \\
1.000\end{array}$ & It specializes in logistics and packaging solutions & $\begin{array}{l}\mathrm{T} 1 \text { and } \mathrm{T} 1: 12 \\
\text { years }\end{array}$ \\
\hline
\end{tabular}




\section{Data analysis}

We conducted the analyses in two stages: (a) codification based on theoretical arguments taken from the previous literature; and (b) codification based on data taken from our interview transcripts (Gibbs, 2007; Miles, Huberman, \& Saldana, 2013).

We began by identifying statements taken from our interview transcripts, and then we drew on common statements to form provisional categories and first-order codes. The codes were then named, and categories of inter-organizational collaboration, operational practices, and capabilities were constructed. We subsequently integrated the first-order codes and created theoretical categories in line with the previously mentioned literature.

Table 4

\section{Profile of management respondents}

\begin{tabular}{|c|c|c|}
\hline \multicolumn{2}{|c|}{ Case/Respondents } & \multirow{2}{*}{$\begin{array}{l}\text { Description of the respondents } \\
\text { Logistics manager, male, age } 42,12 \text { years with the firm }\end{array}$} \\
\hline \multirow{7}{*}{1} & M9: OEM-C1 & \\
\hline & M10: T1a-C1 & Client portfolio manager, male, age 38 , four years with the firm \\
\hline & M11: T1a-C1 & Quality and R\&D manager, male, age 55,29 years with the firm \\
\hline & M12: T1b-C1 & The manager responsible for Powertrain Division, male, age 38, eight years with the firm \\
\hline & M13: T2-C1 & Client portfolio manager, male, age 54 , six years with the firm \\
\hline & M14: T2-C1 & Quality and $R \& D$ manager, male, age 39,12 years with the firm \\
\hline & M15: T2-C1 & Operations manager, male, age 42,11 years with the firm \\
\hline \multirow{8}{*}{2} & M1: OEM-C2 & Logistics manager, male, age 54,25 years with the firm \\
\hline & M2: T1-C2 & Client portfolio manager, male, age 53,32 years with the firm \\
\hline & M3: T1-C2 & Business manager, male, age 37 , ten years with the firm \\
\hline & M4: T1-C2 & Supply chain service manager, age 32 , six years with the firm \\
\hline & M5: T1-C2 & Materials administration manager, age 62,32 years with the firm \\
\hline & M6: T1-C2 & $\begin{array}{l}\text { The manager responsible for the quality and assessment of suppliers, age } 38,12 \text { years with the } \\
\text { firm }\end{array}$ \\
\hline & M7: T2-C2 & Client portfolio manager, male, age 45,23 years with the firm \\
\hline & M8: T2-C2 & Quality and R\&D manager, male, age 43,15 years with the firm \\
\hline \multirow{5}{*}{3} & M16: OEM & Global supply service manager, age 45,16 years with the firm \\
\hline & M17: T1-C3 & Supply chain service manager, age 39,14 years with the firm \\
\hline & M18: T1-C3 & Quality analyst, age 40 , eight years with the firm \\
\hline & M19: T1-C3 & IT manager, age 39,14 years with the firm \\
\hline & M20: T2-C3 & IT coordinator, age 37 , one year with the firm \\
\hline
\end{tabular}

Finally, we compared the category dimensions and looked at how different categories fitted into a coherent dimension. We re-examined the data fit and the set of categories that had been developed. In the second stage, we analyzed the relationships between the three supply chains based on the conceptual practice and collaborative relationship categories. In the development

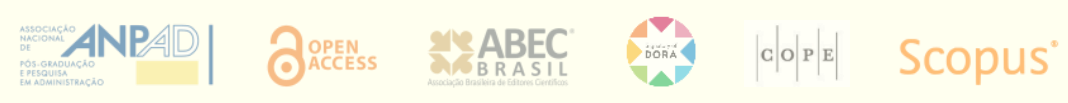


process of supply chain practices, we used the patterns presented by Krause et al. (1998): the strategic and reactive approaches.

We also employed the interaction patterns of the collaborative relationship between firms, based on Hardy et al. (2003): (a) depth, which was classified as shallow, when interactions are restricted to the manager in the buying firm and his/her counterpart in the supply firm; or deep, when the interactions extend to other personnel in both the firms (buyers and suppliers); and (b) scope, which was classified as narrow when interactions occur just in the supply chain analyzed; or broad, when there are also interactions with third parties (for example, a university and/or associate firms).

To analyze information-sharing, we employed information-flow patterns: either unidirectional, bi-directional, or multi-directional (Dyer \& Nobeoka, 2000; Hardy, Phillips, \& Lawrence, 2003), and type of knowledge transfer: either explicit or tacit (Dyer \& Nobeoka, 2000; Grant, 1996). All qualitative data were analyzed by way of content analysis.

\section{Replication}

The research project conducting the case study must ensure the accuracy of the information collected (Yin, 2014). To improve internal validity, we selected each triad from different industries, which provides a more representative sample of the Brazilian economy, while the interviews were conducted with professionals from different hierarchical levels (Lincoln \& Guba, 1985).

To improve external validity, we specified the unit of analysis and the context by way of a dense description (within-case analysis) of each case. We also recorded and transcribed the interviews and then used multiple searches to code them and compare the results. Finally, quotes taken from what the interviewees said are shown to improve objectivity (Lincoln \& Guba, 1985).

\section{RESULTS}

We seek to answer our research question through the qualitative research results. We then identify the constructs of operational practices, inter-organizational collaboration, and the capabilities of the triadic relationships in the supply chains researched.

\section{Within-case analysis}

\section{Case 1-Supply chain capabilities in the automotive sector}

In Case 1, we found the operational capabilities of improvement and customization developed in Supplier T2b through the supplier-suppliers relationship (Figure 1). The improvement capability was found in specific situations. For example, Supplier T1a helped with the improvement process in Supplier T2b for OEE indicators, seeking to increase the efficiency, 
product volume, and delivery of a particular component. This component was highly demanded in the past, and Supplier T2b could not deliver it according to the schedule requested by Supplier T1b. As a result, cross-functional teams from both firms had meetings every two weeks to identify capacity and process quality gains. The Supplier T1b team helped on Supplier T2b's shop floor by introducing Kaizen improvement programs to deal with bottlenecks in the production process and train its employees to reduce waste and increase productivity. Thus, with improvements in the process, it managed to produce the output volume required by Supplier T1b.

Regarding the operational customization capability, Supplier T2b makes specific parts for Supplier T1b, in line with the car project designed by the original equipment manufacturer (OEM). Development takes approximately 18 months. Supplier T1b sends the component project, which has been created and is required by OEM, to Supplier T2b. Supplier T2b duly develops it and analyses the manufacturing cost. The component is eventually tested in the car assembler's plant since OEM sometimes wants to test the component on the prototype of a new model.

Therefore, the operational customization capability was identified. This occurs principally because of Supplier T2b's technical competence, and the tools and processing devices shared between $\mathrm{T} 1 \mathrm{~b}$ and $\mathrm{T} 2 \mathrm{~b}$. Knowledge sharing in the product development process was identified from the interactions between T1b and T2b when Supplier T2 claims that it is impossible to produce the component as specified in the original project for reasons related to machining tolerance.

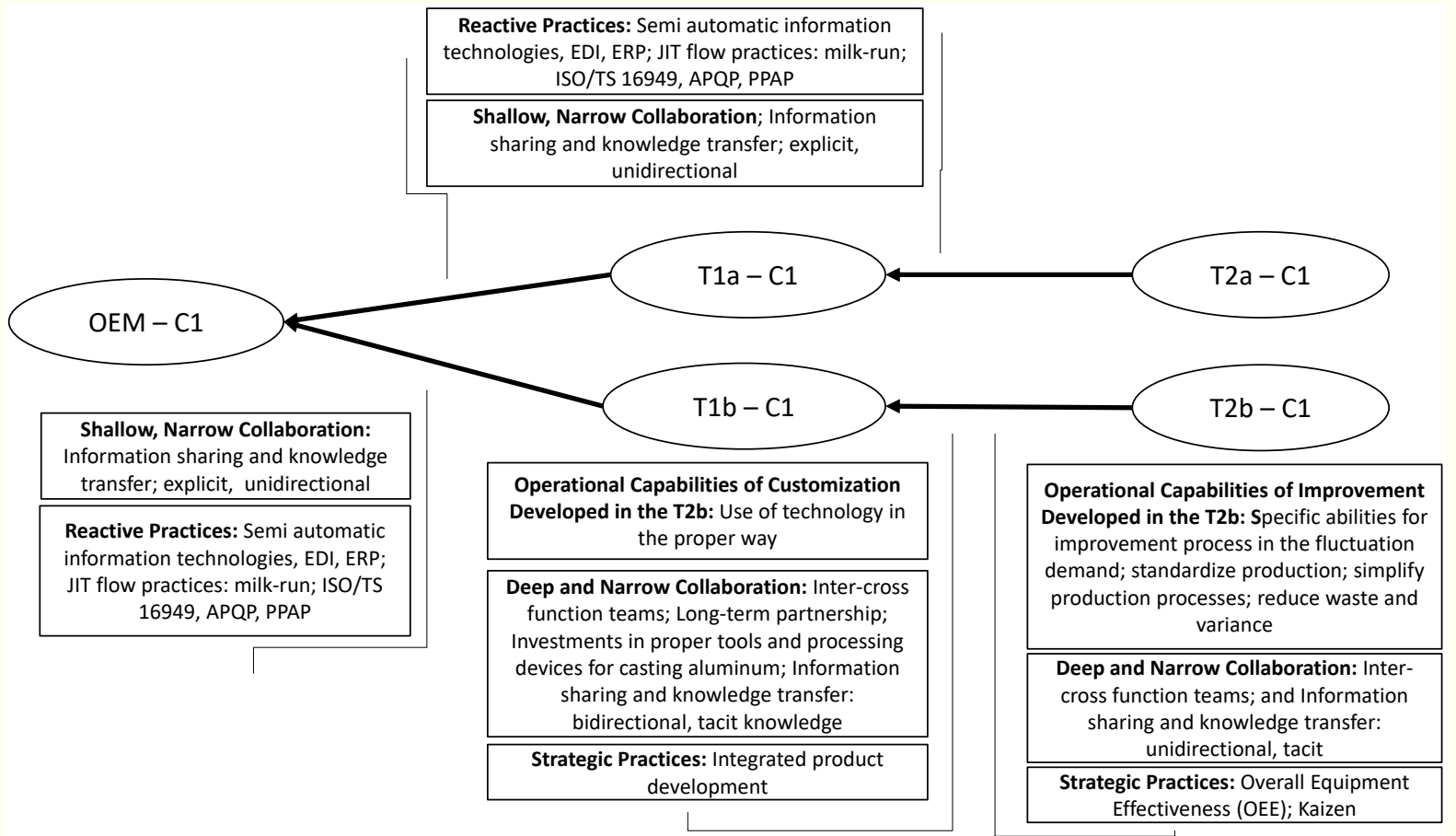

Figure 1. Capabilities developed in the triad in an automotive supply chain.

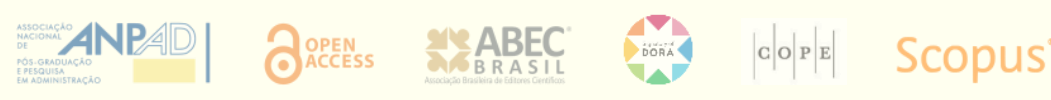


In Case 1, improved capabilities are developed between Suppliers T1 and T2. The buyer develops the entire project, and the suppliers follow its requirements. There is strong collaboration between the two suppliers to achieve the project's requirements, which results in the operational improvement capability being developed in Supplier T2b.

\section{Case 2-Supply chain capabilities in the chemical sector}

This company adopted quality management practices, primarily Lean Six Sigma. OEM purchase orders for Supplier T1 are negotiated with a Supplier T1 account manager (Figure 2). This manager is technically competent and has sufficient autonomy to suggest improvements relating to OEM's production process. Likewise, he possesses the skills needed to develop a closer, more collaborative relationship with OEM. Therefore, the operational improvement capability is driven by the buyer by way of cross-functional teams and Lean Six Sigma projects and is developed by both companies.

Supplier T1's portfolio manager works in OEM's factory twice a week. He has the technical knowledge to analyze productivity and the correct use of the product (abrasives for removing welds, micro-abrasives, and sanders) on OEM's shop floor. The company trains OEM's employees to make better use of its product during the production process. Likewise, it develops Six Sigma projects with OEM. Studies are made of the process cost, with cost data relating to the raw materials used, the machinery, the time taken for employees to become fully skilled in handling the machinery, plus the cost of processing the raw material.

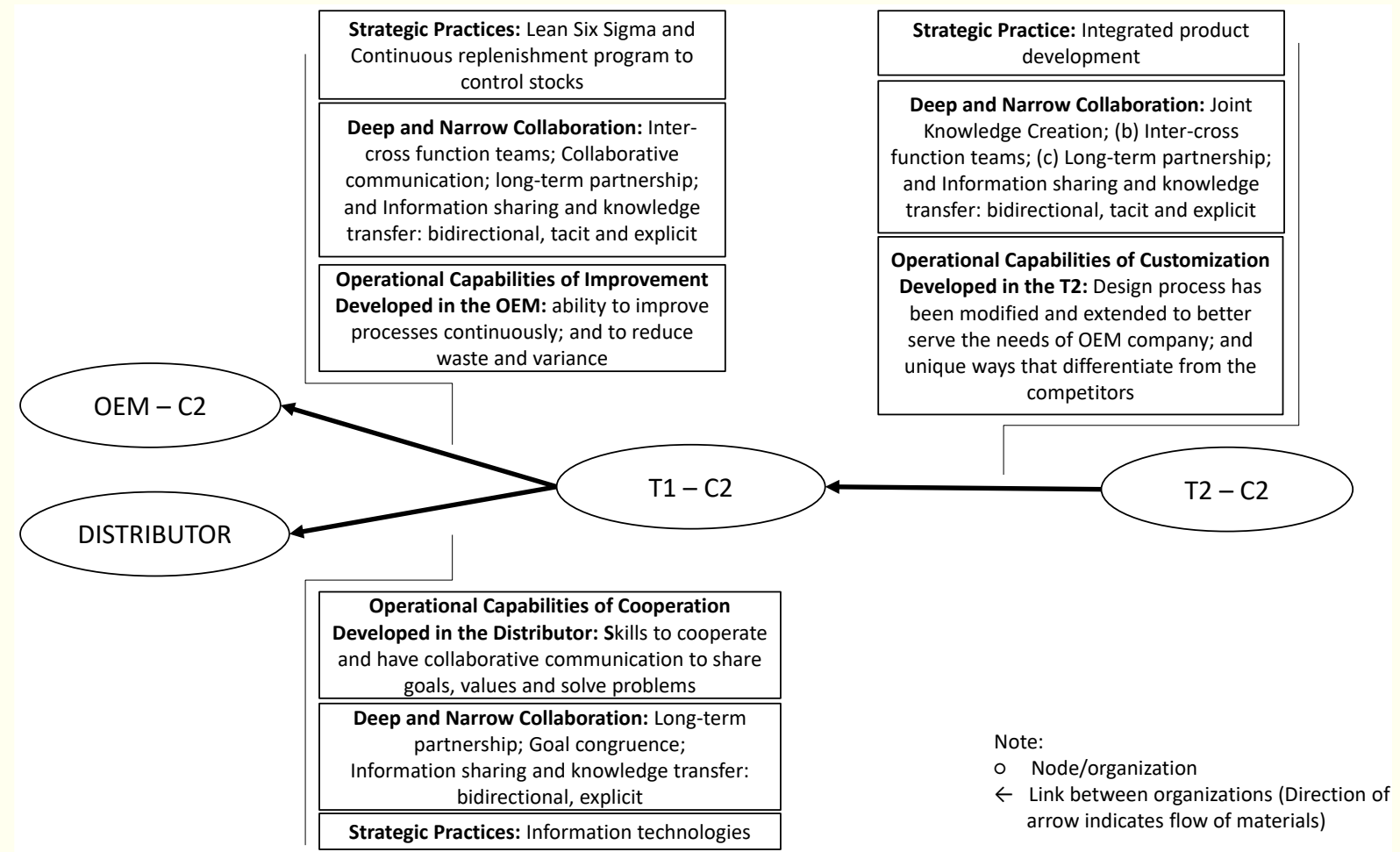

Figure 2. Capabilities developed in the triad in a chemical supply chain.

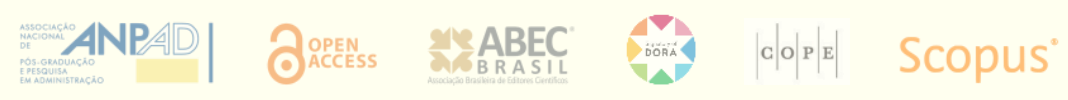


OEM accepts $90 \%$ of the alterations and invests in machinery and new products from Supplier T1, according to the process improvements suggested by Supplier T1. Therefore, the main operational improvement capabilities developed were: (a) the development of new ways of working, through training workers to operate the machines perfectly; (b) continuous improvements in the work team, developing Six Sigma projects in conjunction with the supplier's multifunctional teams and the client; and (c) a continuous reduction in waste and any variance in the product quality process.

OEM uses products from first-tier Supplier T1 in its welding and painting processes. Suppliers T1 and T2 developed a product that contained a specific grain size for OEM's automotive line. The technology employed was not modified, but modifications were made to the grain's density, hardness, and durability. Therefore, the teams formed by the two supply-chain links (T2 T1 $\leftarrow$ OEM) worked together to develop this product for OEM. Supplier T1 shares knowledge and develops customized products with T2 to cater to OEM's needs.

\footnotetext{
"they [the team from the T1 supplier company] do very interesting work with our team [the T2 supplier]. Their engineer [from the T1 supplier] shares his technical competence and informs us of the needs he identifies at the client's premises [OEM] ... we have a record of the knowledge of our material and competence in the electrofusion process ... they [T1] know our production process and our costs [T2] ... we jointly develop a product with assured quality and carry out chemical analysis tests" (Quality and R\&D manager, Supplier T2).
}

We note that Supplier T2 had previous experience in the electrofusion process, and Supplier T1 had customer information and expertise in product development. These skills and the routines for developing the new product represent the customization capability.

Supplier T1 also uses a collaborative relationship and practices with its distributor. The firms share goals and values employing these practices. They also draw up formal plans for annual growth defined in their strategic planning processes, based on the launch of new products. Supplier T1 offers a basic quality training course to the distributor's salespeople and arranges workshops to show the products to end customers. The distributor often invites customers (wholesalers and retailers) to attend these workshops.

The distributor has a supervisor who is an employee of Supplier T1. This supervisor is responsible for keeping up with the distributor's growth and trains the sales personnel. Supplier T1 prepares monthly and quarterly reports about the products sold. There is a feedback meeting on these results when the lifecycle of the products is assessed, and new products and technologies are presented. In summary, the supervisors transfer explicit knowledge using collaborative communication (meetings and workshops) and customer-orientation practices (CRM and CPFR). On this point, we were able to identify the operational cooperation capability, with Supplier T1 having the skills needed to develop an information system that facilitated communication with the distributor.

The results of our study revealed three capabilities in the supply chain's triadic relationship in Case 2: (a) the operational improvement capability, which was only identified in OEM; (b) the

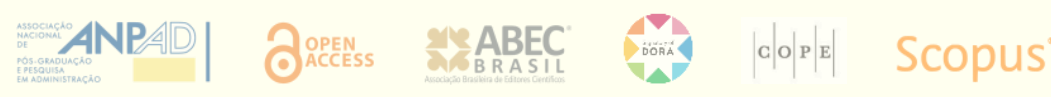


operational customization capability, which was identified in Tier 2; and (c) the operational cooperation capability, which was found in the distributor (Figure 1). A summary of the capabilities that result from inter-organizational collaboration and operational practices is presented in Figure 2.

Therefore, in Case 2, an open triad, we identified that OEM and the first-tier supplier dyad make a considerable effort to develop their improvement capabilities. Supplier T1 transmits these practices and routines to Supplier T2. Therefore, Supplier T1 has an important role in this supply chain by serving as a diffuser of practices and capabilities.

\section{Case 3: Supply chain capabilities in the electrical-electronic sector}

The operational responsiveness capability was found in Supplier T1 (Figure 3). Supplier T1 manages the whole component purchase process of Supplier T2, which includes negotiating components, logistics management, and inbound/outbound distribution. It is also responsible for customs dispatch for imported components and the exportation and delivery of finished goods.

Communication about purchases and sales between Supplier T1 and OEM involves using the EDI system, email, and telephone. Sales orders are planned quarterly, but demand frequently fluctuates within this period; orders, therefore, are rescheduled every 24 hours. Contract terms are established monthly as the first negotiation and management of these products' logistics. On average, 90 days, given that all the components are imported from Asia. OEM's operations manager has an office with a team of eight staff in Supplier T1's plant. It monitors negotiations with Supplier T2, provides flexibility in delivery and volume, and guarantees delivery, primarily because of frequent demand fluctuations. 


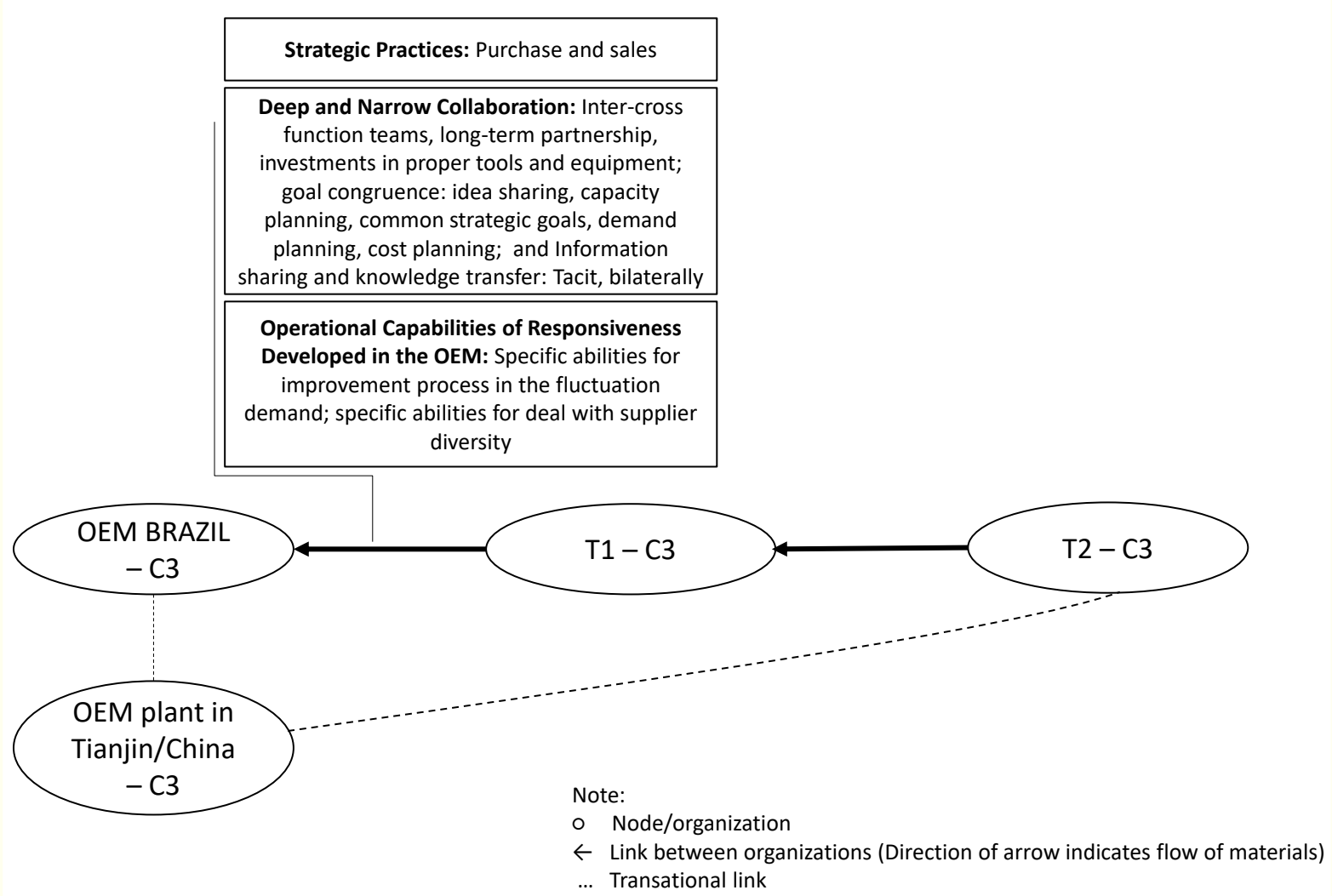

Figure 3. Capabilities developed in the electronic supply chain triad.

The sales contracts specify the number of components to be purchased and the time taken for assembly and delivery of the finished product. When demand fluctuates, as it frequently does, OEM may have to bear any excess transportation and product costs incurred by Supplier T2. OEM is aware of Supplier T1's raw material and finished product stock situation in real time. OEM approves all Suppliers T2 and determines the price they will pay for the component.

Supplier T1 has negotiation strategies for the purchasing process. One is called global supply chain management, which involves a team responsible for the corporation's purchases. This firm has operations in 26 countries. Supplier T1 also has employees responsible for negotiating purchases with offices in Asia. It facilitates communication with T2 suppliers since they speak the same language and conduct negotiations during the same business hours as these suppliers.

The operational responsiveness capability was identified in the product purchase and sales processes. It is a crucial capability in this case because suppliers are located abroad, and this aspect can jeopardize delivery time. For example, OEM's supply chain operations manager reported that there had been an upswing in demand, over and above the initial projection of 1,500 units. In fact, in the third week of April 2012, the forecast was adjusted to 6,000. In response, OEM imported three pieces of equipment in four days from another factory located in Mexico for use in T1's factory. This allowed T1 to increase its production capacity, assemble the required number of products, and deliver on time. Furthermore, OEM was involved directly in the negotiations

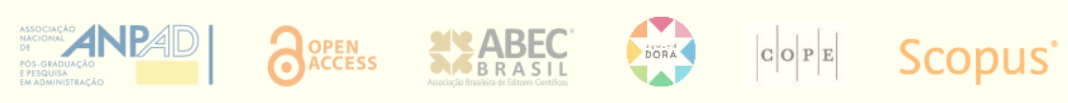


for components with the second-tier suppliers. The negotiations were mediated by the factory located in Tianjin, China.

"our relationship with Supplier T1 goes beyond the contract. If the contract manufacturer obtains components directly from the second-tier suppliers at low cost and in bulk, the components will reach Brazil by sea. This would take 50 days, as the route is not the standard one ... when demand fluctuates, I'm faced with a huge problem to solve" (Supply chain manager, OEM).

In this case, the components were bought from the OEM plant in Tianjin and dispatched by air and took five working days to reach Supplier T1's factory. At the time of the interview, OEM's and Supplier T1's managers arranged a trip to Asia to hold meetings with Supplier T2 and change suppliers' network. They stressed that they trusted their partnership, which entailed transparency between the parties, competent logistics management processes, and the product brand's reputation. We found a transitional relationship between Supplier Tier 2 and the OEM plant in Tianjin. We classified this chain as a transitional triad since the OEM plant in Brazil had previously initiated the relationship with OEM's Tianjin plant, introducing a new Tier 2 supplier to the Tier 1 supplier (Figure 3).

Supplier T1 also has direct contact with Tier T2 to control the packing inventory and get it just in time. The EDI system sends production orders. The second-tier supplier works with the JIT system with the first-tier supplier, delivering packaging more than once a day, saving T1 supplier inventory costs. In this case, we identified no capabilities that had been developed between Supplier T1 and Supplier T2. Figure 3 illustrates the multi-tier structure of this supply chain.

Therefore, in Case 3, the buyer is present in the entire supply chain to ensure that practices and capabilities are disseminated and that the quality standards of the product are maintained. The buyer also works to ensure chain responsiveness to accommodate sudden changes in product demand. Our study expands on the current literature by identifying improvement and responsiveness capabilities related to quality management practices from a triadic perspective.

\section{Cross-case analysis}

After all the cases had been individually analyzed, we carried out cross-case analyses. In the operational improvement capability that we identified in Cases 1 and 2 as supplier-supplier and buyer-supplier relationships, we found that this capability emerged from practices involving the quality area and communication technologies (OEE and Kaizen in Case 1; Lean Six Sigma and VMI in Case 2). In both cases, the focus on adopting these practices was located at the strategic level.

Although some practices were present in the relationships, such as information technology practices, milk-run, and quality management control practices, those practices in the automotive industry (Case $1, \mathrm{OEM} \leftarrow \mathrm{T} 1 \mathrm{~b} \leftarrow \mathrm{T} 2 \mathrm{~b}$; and $\mathrm{OEM} \leftarrow \mathrm{T} 1 \mathrm{a} \leftarrow \mathrm{T} 2 \mathrm{a}$ ) were not sufficient for developing operational capabilities (Figure 2). These practices were reactive, with companies adopting them to control product quality and supplier stocks. We identified a shallow collaborative relationship within the triad. Supplier T1a, for example, complained that OEM did not provide support for

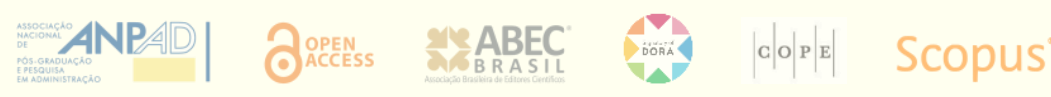


new investments and that any improvements in product development or the manufacturing process are very slow.

Our results reveal that operational capabilities occurred only in the second link of the automotive supply chain (Supplier T1a T2a), where there was a multinational company (T1a) and a local company (T2a). We identified a collaborative relationship that was both profound and close, including multifunctional teams and intra-firm communication. These collaborative relationships were aligned with supply chain practices, such as Kaizen, OEE, and integrated product development.

Therefore, there was tacit, unidirectional, and bidirectional knowledge sharing in the processes we analyzed. The operational improvement capability arises from the whole of the knowledge flow since there was demand fluctuation. Supplier T1a supported Supplier T2a in the Kaizen and OEE programs to increase production capacity and reduce waste. The improvement capability, therefore, increased competence and output and reduced waste.

On the other hand, Supplier T1a increased its operational performance by way of low costs and responsiveness to buyer needs. Krause et al. (1998) stated that companies tread an evolutionary path to supplier development. The first step is adopting TQM practices, followed by supplier evaluation and a reduction in the number of suppliers, with the most advanced stage being related to supply development strategies. In Case 1 and Case 2, the operational improvement capability also improved quality management practices.

The operational customization capability in the $\mathrm{T} 1 \mathrm{a} \leftarrow \mathrm{T} 2 \mathrm{a}$ dyad was also present in integrated product development (automotive industry). Supplier T1a invested in Supplier T2a and supplied it with tools and devices for new product development, and both suppliers share knowledge to

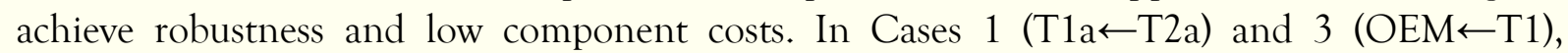
investment in proper tools and equipment (Case 3) is a relevant action (Case 3), as are investments by Supplier T1a in training for T2a (Case 1) (Figures 1 and 3). At this point, we identified that even in open, multi-tier supply chain structures (MSC), companies have considerable investments and greater interdependence in terms of the development of their capabilities. Wu et al. (2010) consider the following operational capabilities: improvement, customization, responsiveness, and cooperation.

We identified that all four operational capabilities resulted in close supply chain collaboration between firms. The common supply chain collaboration method adopted in the development of these four capabilities involved cross-functional teams and collaborative communication. The results suggest that involvement in buyer-supplier relationships and having cross-functional teams are critical to supplier development. Moreover, there was bilateral knowledge transfer allowing firms to learn from each other. These findings confirm Hardy et al.'s (2003) suppositions about what involvement is necessary for first-order learning, allowing partners to identify key resources and, consequently, develop core competencies and achieve competitive advantage. 


\section{DISCUSSIONS}

Although the OSCM literature recognized the importance of a multi-tier approach in supply chain research (Demirel et al., 2019; Ta et al., 2018; Wynstra et al., 2015; Zhang et al., 2015), most studies still focus on collaboration restricted to dyadic relationships (Gong et al., 2018; Sauer \& Seuring, 2019; Wilhelm et al., 2016). However, triads include several interactions that involve buyers, suppliers, and clients, which can enlarge our understanding of collaboration in different triadic structures (Mena et al., 2013). Our findings suggest that collaboration opens room for capabilities development in the practice-adoption process through triads. Moreover, triadic structures affect the interaction between supply chain partners and how they collaborate (Mena et al., 2013; Ta et al., 2018; Wynstra et al., 2015; Zhang et al., 2015).

Past studies had shown that collaboration in dyadic relationships improves information and resource sharing (Gong et al., 2018; Nimmy et al., 2019; Sauer \& Seuring, 2019; Wilhelm et al., 2016); however, triadic structures have an important role in this process. We found that the role of each tier in the development of capabilities is different in the cases. Cases 1 and 2 are open triads, where the buyer has no direct connection to second-tier suppliers. Collaboration occurs only in dyadic-diffused relationships in those triads (supplier-supplier or buyer-supplier), focusing on quality (Escrig-Tena, Segarra-Ciprés, \& García-Juan, 2021) and involving communication technologies (Fatorachian \& Kazemi, 2021; Mena et al., 2013; Parente, Murray, Zhao, Kotabe, $\&$ Dias, 2020). Our findings suggest that first-tier suppliers develop capabilities with a partner and diffuse information and knowledge throughout the entire triad (Demirel et al., 2019; Fatorachian \& Kazemi, 2021; Parente et al., 2020; Ta et al., 2018; Wynstra et al., 2015; Zhang et al., 2015).

Our results suggested that the first-tier supplier has a role to play in orchestrating the supply chain when there is little collaboration on the part of the buyer in the supply chain or when collaboration is restricted to the direct suppliers. In the supplier-supplier relationship, this 'middleman' collaborates with the second-tier supplier to archive the buyer' requirements for quality in non-collaborative supply chains (Case 1), developing improvement capabilities in the process; and it diffuses practices and routines learned from buyer to second-tier supplier in supply chains embedded in dyadic collaborations (Case 2). That enlarge past studies on triads (Ta et al., 2018; Wynstra et al., 2015; Zhang et al., 2015), highlighting the importance of first-tier suppliers in an open triadic structure.

Despite the importance of the first-tier supplier in the practice-adoption process, results suggest that it has a limited role in the absence of a collaborative buyer. In Case 3, a transitional triad, the buyer is concerned that the same quality standards should be followed throughout the entire supply chain, sharing practices, tools, and equipment with the partners. Moreover, the buyer collaborates to ensure that its suppliers have sufficient materials to accommodate sudden changes in demand, which results in greater responsiveness for the triad. In transaction and closed triad structures, the sense of interdependence is more significant among its members, allowing the buyer to influence product characteristics and performance (Mena et al., 2013). Past studies had presented the practice-adoption process as a source of capabilities for supply chains (Amrani $\&$

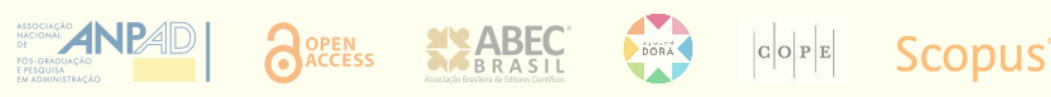


Ducq, 2020; Bianchi \& Ferraz, 2020; Khalfallah \& Lakhal, 2020; Zimmermann et al., 2020). Our results highlight the importance of the buyer in the collaborative practice-adoption process, essential in the development of additional capabilities for triads.

\section{CONCLUSIONS}

Our study brings new insights for understanding capability development through a practiceadoption process from an inter-organizational collaboration in the triadic perspective. First, the results indicate that capabilities can be created from practices related to buyer and supplier interactions and the interactions between suppliers. The focal company plays a central role in capabilities development, but supplier-supplier interactions can also create or strengthen operational capabilities. These results suggest that the collaborative implementation of TQM, NPD, and IT practices enables different operational capability types to be developed between focal companies and a Tier 1 supplier and between Tier 1 and Tier 2 suppliers, such as responsiveness, improvement, cooperation, and customization.

Moreover, our findings suggest that triadic structures play an important role in the collaborative practice-adoption process. Open triads are more dependent on first-tier suppliers for diffusing information throughout partners, ensuring that buyers' practices reach second-tier suppliers. However, the buyer needs to enhance the second-tier supplier to develop some capabilities, such as responsiveness. It orchestrates information and resources in the entire triad, expanding its structure to at least a transitional triad, increasing capability development.

\section{Managerial implications}

Our study has managerial implications as well. Triads provide supplier development by disseminating the learning of capabilities and practices throughout supply chains, benefiting firstand second-tier suppliers. Buyers should focus their investment efforts on potential and qualified suppliers, align their goals, and seek a long-term partnership. Companies must identify critical areas for improvement and extend capabilities and practices to their suppliers, increasing the autonomy of first-tier suppliers to conduct second-tier suppliers. Moreover, the study of the triad in the supply chain benefits the customer and society, as the goods/services generated are produced according to more stringent criteria, reducing risks, complying with regulations and higher standards. Therefore, practices and capabilities are evaluated throughout the chain and, consequently, contribute to reducing the negative impacts of products and services.

\section{Research limitations and suggestions for future studies}

Our study has limitations that point to unanswered questions for future research. Although we presented the development of operational capabilities in three case studies in details, using multiple interviews and a multi-tier supply chain, the limitation of our study might be our sample size. Since we could not analyze the data by industry, our analysis is limited to our results' generalizability. The impact of the industry and country was not explicitly investigated in this

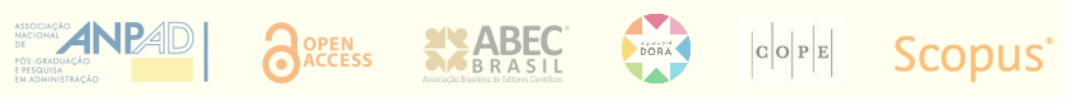


study and extending our findings to include other contexts should be done cautiously.

We also believe that future studies might consider other operational capabilities, such as the operational reconfiguration capability. We could find no evidence in our case studies for this capability. The reconfiguration capability is used in environmental businesses to deal with radical changes and the concept of dynamic capabilities. Future studies may find evidence for the reconfiguration capability if the focus is on a single industry, or a contingency approach is adopted.

Future studies could also look at other triadic relationships, such as the closed structure, and see how the capabilities are developed; we found only the open and transactional triad structure in our study. Mena et al. (2013) suppose that there is a large volume of resource investments in closed triads, and we suggest that this may motivate the development of other capabilities that were not found in this study. This study contributes to our understanding of the role of collaboration in operational capabilities in the practice-adoption process and the triadic perspective in three industrial sectors in Brazil. The debate on this matter is intense and thoughtprovoking in the supply chain management literature.

\section{REFERENCES}

Alsawafi, A., Lemke, F., \& Yang, Y. (2021). The impacts of internal quality management relations on the triple bottom line: A dynamic capability perspective. International Journal of Production Economics, 232. https://doi.org/10.1016/j.ijpe.2020.107927

Amrani, A., \& Ducq, Y. (2020). Lean practices implementation in aerospace based on sector characteristics: methodology and case study. Production Planning and Control, 31(16), 1313-1335. https://doi.org/10.1080/09537287.2019.1706197

Barratt, M., Choi, T. Y., \& Li, M. (2011). Qualitative case studies in operations management: Trends, research outcomes, and future research implications. Journal of Operations Management, 29(4), $329-342$. https://doi.org/10.1016/j.jom.2010.06.002

Bianchi, E. M. P. G., \& Ferraz, S. Junior (2020). e-Qualifácil: Preparing small businesses for a quality management system. Brazilian Administration Review, 17(1), e180154. https://doi.org/10.1590/1807-7692bar2020180154

Braziotis, C., Tannock, J. D. T., \& Bourlakis, M. (2017). Strategic and operational considerations for the Extended Enterprise: insights from the aerospace industry. Production Planning $\mathscr{E}$ Control, 28(4), 267-280. http://doi.org/10.1080/09537287.2016.1268274

Bromiley, P., \& Rau, D. (2014). Towards a practice-based view of strategy. Strategic Management Journal, 35(8), 1249. 1256. https://doi.org/10.1002/smj.2238

Cao, M., \& Zhang, Q. (2011). Supply chain collaboration: Impact on collaborative advantage and firm performance. Journal of Operations Management, 29(3), 163-180.

Choi, T. Y., \& Wu, Z. (2009). Taking the leap from dyads to triads: Buyer-supplier relationships in supply networks. Journal of Purchasing and Supply Management, 15(4), 263-266. https://doi.org/10.1016/j.pursup.2009.08.003

Claycomb, C., Germain, R., \& Dröge, C. (1999). Total system JIT outcomes: inventory, organization and financial effects. International Journal of Physical Distribution $\mathcal{E}$ Logistics Management, 29(10), 612-630. http://dx.doi.org/10.1016/j.jom.2010.12.008

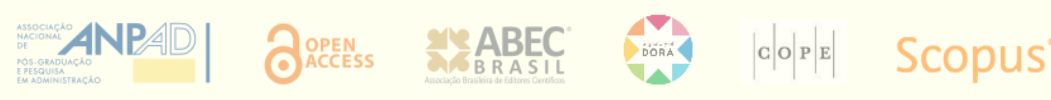


Day, M., Fawcett, S. E., Fawcett, A. M., \& Magnan, G. M. (2013). Trust and relational embeddedness: Exploring a paradox of trust pattern development in key supplier relationships. Industrial Marketing Management, 42(2), 152. 165. https://doi.org/10.1016/J.INDMARMAN.2012.12.004

Demirel, G., MacCarthy, B. L., Ritterskamp, D., Champneys, A. R., \& Gross, T. (2019). Identifying dynamical instabilities in supply networks using generalized modeling. Journal of Operations Management, 65(2), 136-159. http://doi.org/10.1002/joom.1005

Dong, Y., Carter, C. R., \& Dresner, M. E. (2001). JIT purchasing and performance: An exploratory analysis of buyer and supplier perspectives. Journal of Operations Management, 19(4), 471-483. http://dx.doi.org/10.1016/S02726963(00)00066-8

Dyer, J. H., \& Nobeoka, K. (2000). Creating and managing a high-performance knowledge-sharing network: The Toyota case. Strategic Management Journal, 21(3), 345-367. http://dx.doi.org/10.1002/(SICI)10970266(200003)21:3\%3C345::AID-SMJ96\%3E3.0.CO;2-N

Dyer, J. H., \& Singh, H. (1998). The relational view: Cooperative strategy and sources of interorganizational competitive advantage. Academy of Management Review, 23(4), 660-679. https://doi.org/10.2307/259056

Eisenhardt, K. M. (1989). Building theories from case-study research. Academy of Management Review, 14(4), 532-550. https://doi.org/10.2307/258557

Eltantawy, R., Paulraj, A., Giunipero, L., Naslund, D., \& Thute, A. (2015). Towards supply chain coordination and productivity in a three echelon supply chain: Action research study. International Journal of Operations \& amp; Production Management, 35(6), 895-924. https://doi.org/10.1108/IJOPM-10-2013-0459

Escrig-Tena, A. B., Segarra-Ciprés, M., \& García-Juan, B. (2021). Incremental and radical product innovation capabilities in a quality management context: Exploring the moderating effects of control mechanisms. International Journal of Production Economics, 232. https://doi.org/10.1016/j.ijpe.2020.107994

Fatorachian, H., \& Kazemi, H. (2021). Impact of Industry 4.0 on supply chain performance. Production Planning and Control, 32(1), 63-81. https://doi.org/10.1080/09537287.2020.1712487

Fawcett, S. E., McCarter, M. W., Fawcett, A. M., Webb, G. S., \& Magnan, G. M. (2015). Why supply chain collaboration fails: the socio-structural view of resistance to relational strategies. Supply Chain Management, 20(6), 648-663. https://doi.org/10.1108/SCM-08-2015-0331

Flynn, B. B., Sakakibara, S., \& Schroeder, R. G. (1995). Relationship between JIT and TQM: practices and performance. Academy of Management Journal, 38(5), 1325-1360. https://doi.org/10.5465/256860

Frohlich, M. T., \& Westbrook, R. (2001). Arcs of integration: an international study of supply chain strategies. Journal of Operations Management, 19(2), 185-200. http://dx.doi.org/10.1016/S0272-6963(00)00055-3

Gibbs, G. R. (2007). Analyzing qualitative data. CA: Sage.

Gong, Y., Jia, F., Brown, S., \& Koh, L. (2018). Supply chain learning of sustainability in multi-tier supply chains: A resource orchestration perspective. International Journal of Operations E Production Management, 38(4), 1061-1090. https://doi.org/10.1108/IJOPM-05-2017-0306

Grant, R. M. (1996). Prospering in dynamically-competitive environments: Organizational capability as knowledge integration. Organization Science, 7(4), 375-387. http://dx.doi.org/10.1287/orsc.7.4.375

Hardy, C., Phillips, N., \& Lawrence, T. B. (2003). Resources, knowledge and influence: The organizational effects of inter Organizational collaboration. Journal of Management Studies, 40(2), 321-347. https://doi.org/10.1111/1467-6486.00342

International Monerary Fund (2011). New growth drivers for low-income countries: The role of BRICs. Retrieved from http://www.imf.org/external/np/pp/eng/2011/011211.pdf

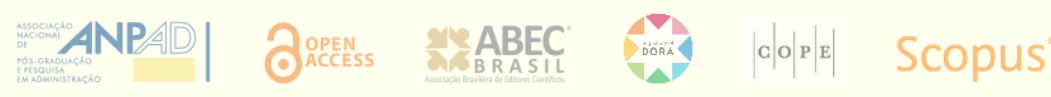


Kannan, D. (2021). Sustainable procurement drivers for extended multi-tier context: A multi-theoretical perspective in the Danish supply chain. Transportation Research Part E: Logistics and Transportation Review, 146, 1-28. https://doi.org/10.1016/j.tre.2020.102092

Kaynak, H. (2002). The relationship between just-in-time purchasing techniques and firm performance. IEEE Transactions on Engineering Management, 49(3), 205-217. http://dx.doi.org/10.1109/TEM.2002.803385

Khalfallah, M., \& Lakhal, L. (2020). The impact of lean manufacturing practices on operational and financial performance: the mediating role of agile manufacturing. International Journal of Quality and Reliability Management, 38(1), 147-168. https://doi.org/10.1108/IJQRM-07-2019-0244

Kotabe, M., Martin, X., \& Domoto, H. (2003). Gaining from vertical partnerships: Knowledge transfer, relationship duration, and supplier performance improvement in the U.S. and Japanese automotive industries. Strategic Management Journal, 24(4), 293-316. https://doi.org/10.1002/smj.297

Kotha, S., \& Swamidass, P. M. (2000). Strategy, advanced manufacturing technology and performance: empirical evidence from U.S. manufacturing firms. Journal of Operations Management, 18(3), 257-277. http://dx.doi.org/10.1016/S0272-6963(99)00025-X

Kotzab, H., Teller, C., Grant, D. B., \& Friis, A. (2015). Supply chain management resources, capabilities and execution. Production Planning \& Control, 26(7), 525-542. https://doi.org/10.1080/09537287.2014.927932

Krause, D. R., Handfield, R. B., \& Scannell, T. V. (1998). An empirical investigation of supplier development: Reactive and strategic processes. Journal of Operations Management, 17(1), 39-58. https://doi.org/10.1016/S0272. $6963 \% 2898 \% 2900030-8$

Lanier, D., Wempe, W. F., \& Zacharia, Z. G. (2010). Concentrated supply chain membership and financial performance: Chain- and firm-level perspectives. Journal of Operations Management, 28(1), 1-16. https://doi.org/10.1016/j.jom.2009.06.002

Liao, S. H., Hu, D. C., \& Ding, L. W. (2017). Assessing the influence of supply chain collaboration value innovation, supply chain capability and competitive advantage in Taiwan's networking communication industry. International Journal of Production Economics, 191, 143-153. https://doi.org/10.1016/j.ijpe.2017.06.001

Lincoln, Y. S., \& Guba, E. G. (1985). Establishing trustworthiness (pp. 289-331). In Naturalistic Inquiry. Thousand Oaks, CA: SAGE.

Madhok, A. (2002). Reassessing the fundamentals and beyond: Ronald Coase, the transaction cost and resourcebased theories of the firm and the institutional structure of production. Strategic Management Journal, 23(6), 535 550. https://doi.org/10.1002/smj.247

Mena, C., Humphries, A., \& Choi, T. Y. (2013). Toward a Theory of Multi-Tier Supply Chain Management. Journal of Supply Chain Management, 49(2), 58-77. https://doi.org/10.1111/jscm.12003

Meredith, J. R. (1993). Theory building through conceptual methods. International Journal of Operations $\mathcal{E}$ Production Management, 13(5), 3-11. https://doi.org/10.1108/01443579310028120

Miles, M. B., Huberman, A. M., \& Saldana, J. (2013). Qualitative data analysis: A methods sourcebook. Thousand Oaks, CA: SAGE.

Monczka, R. M., Petersen, K. J., Handfield, R. B., \& Ragatz, G. L. (1998). Success factors in strategic supplier alliances: The buying company perspective. Decision Sciences, 29(3), 553-573. http://dx.doi.org/10.1111/j.15405915.1998.tb01354.x

Morgan, R. M., \& Hunt, S. D. (1994). The Commitment-Trust Theory of Relationship Marketing. Journal of Marketing, 58(3), 20-38. https://doi.org/10.2307/1252308

Nimmy, J. S., Chilkapure, A., \& Pillai, V. M. (2019). Literature review on supply chain collaboration: comparison of various collaborative techniques. Journal of Advances in Management Research, 16(4), 537-562. https://doi.org/10.1108/JAMR-10-2018-0087

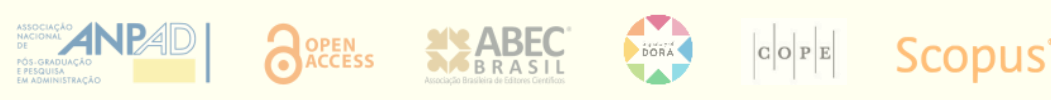


Parente, R., Murray, J. Y., Zhao, Y., Kotabe, M., \& Dias, R. (2020). Relational resources, tacit knowledge integration capability, and business performance. Journal of Knowledge Management. https://doi.org/10.1108/JKM-07-2020. 0501

Prajogo, D., Mena, C., \& Chowdhury, M. (2021). The role of strategic collaborations and relational capital in enhancing product performance: A moderated-mediated model. International Journal of Operations and Production Management, 41(3), 206-226. https://doi.org/10.1108/IJOPM-05-2020-0256

Ramanathan, U., \& Gunasekaran, A. (2014). Supply chain collaboration: Impact of success in long-term partnerships. International Journal of Production Economics, 147(Part B), 252-259. https://doi.org/10.1016/j.ijpe.2012.06.002

Sauer, P. C., \& Seuring, S. (2019). Extending the reach of multi-tier sustainable supply chain management - Insights from mineral supply chains. International Journal of Production Economics, 217, 31-43. https://doi.org/10.1016/j.ijpe.2018.05.030

Saunila, M., Ukko, J., Rantala, T., Nasiri, M., \& Rantanen, H. (2020). Preceding operational capabilities as antecedents for productivity and innovation performance. Journal of Business Economics, 90(4), 537-561. https://doi.org/10.1007/s11573-019-00963-0

Silveira, G. J. C. da, \& Arkader, R. (2007). The direct and mediated relationships between supply chain coordination investments and delivery performance. International Journal of Operations $\mathcal{E}$ Production Management, 27(2), 140158. https://doi.org/10.1108/01443570710720595

Sheu, C., Yen, H. R., \& Chae, B. (2006). Determinants of supplier-retailer collaboration: Evidence from an international study. International Journal of Operations and Production Management, 26(1), 24-49. https://doi.org/10.1108/01443570610637003

Sroufe, R., \& Curkovic, S. (2008). An examination of ISO 9000:2000 and supply chain quality assurance. Journal of Operations Management, 26(4), 503-520. https://dx.doi.org/10.1016/j.jom.2007.06.006

Swanson, D., Jin, Y. H., Fawcett, A. M., \& Fawcett, S. E. (2017). Collaborative process design: A dynamic capabilities view of mitigating the barriers to working together. The International Journal of Logistics Management, 28(2), 571 599. https://doi.org/10.1108/IJLM-02-2016-0044

Swink, M., \& Hegarty, W. H. (1998). Core manufacturing capabilities and their links to product differentiation. International Journal of Operations and Production Management, 18(4), 374-396. https://doi.org/10.1108/01443579810199748

Ta, H., Esper, T. L., \& Hofer, A. R. (2018). Designing crowdsourced delivery systems: The effect of driver disclosure and ethnic similarity. Journal of Operations Management, 60, 19-33. https://doi.org/10.1016/j.jom.2018.06.001

Tan, K. C., Kannan, V. R., \& Narasimhan, R. (2007). The impact of operations capability on firm performance. International Journal of Production Research, 45(21), 5135-5156. https://doi.org/10.1080/00207540600871269

Timans, W., Antony, J., Ahaus, K., \& Van Solingen, R. (2012). Implementation of Lean Six Sigma in small- and medium-sized manufacturing enterprises in the Netherlands. Journal of the Operational Research Society, 63(3), 339353. http://dx.doi.org/10.1057/jors.2011.47

Wagner, S. M., \& Bukó, C. (2005). An empirical investigation of knowledge-sharing in networks. Journal of Supply Chain Management, 41(4), 17-31. https://doi.org/10.1111/j.1745-493X.2005.04104003.x

Wilhelm, M. M., Blome, C., Bhakoo, V., \& Paulraj, A. (2016). Sustainability in multi-tier supply chains: Understanding the double agency role of the first-tier supplier. Journal of Operations Management, 41, 42-60. https://doi.org/10.1016/j.jom.2015.11.001

Wu, S. J., Melnyk, S. A., \& Flynn, B. B. (2010). Operational capabilities: The secret ingredient. Decision Sciences, 41(4), 721-754. https://doi.org/10.1111/j.1540-5915.2010.00294.x

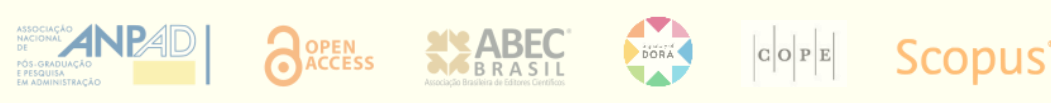


Wu, S. J., Melnyk, S. A., \& Swink, M. (2012). An empirical investigation of the combinatorial nature of operational practices and operational capabilities: Compensatory or additive? International Journal of Operations and Production Management, 32(2), 121-155. http://dx.doi.org/10.1108/01443571211208605

Wu, Z., \& Choi, T. Y. (2005). Supplier-supplier relationships in the buyer-supplier triad: Building theories from eight case studies. Journal of Operations Management, 24(1), 27-52. http://dx.doi.org/10.1016/j.jom.2005.02.001

Wynstra, F., Spring, M., \& Schoenherr, T. (2015). Service triads: A research agenda for buyer-supplier-customer triads in business services. Journal of Operations Management, 35(1), 1-20. https://doi.org/10.1016/j.jom.2014.10.002

Yin, R. K. (2014). Case study research: design and methods (5th ed.). Thousand Oaks, CA: Sage.

Zhang, J., Guo, J., Jiang, J., Wu, X., \& Jiang, R. (2021). Moderating effect of requirements uncertainty on task interdependence and NPD performance. Industrial Management and Data Systems, 121(2), 456-477. https://doi.org/10.1108/IMDS-08-2020-0490

Zhang, J. J., Lawrence, B., \& Anderson, C. K. (2015). An agency perspective on service triads: Linking operational and financial performance. Journal of Operations Management, 35(1), 56-66. https://doi.org/10.1016/j.jom.2014.10.005

Zhang, Q., \& Cao, M. (2015 July). Impact of supply chain long-term orientation on product quality: An empirical examination. Paper presented at the 2015 International Conference on Logistics, Informatics and Service Science, LISS 2015. Barcelona, Spain. https://doi.org/10.1109/LISS.2015.7369660

Zhang, Q., \& Cao, M. (2018). Exploring antecedents of supply chain collaboration: Effects of culture and interorganizational system appropriation. International Journal of Production Economics, 195, 146-157. https://doi.org/10.1016/j.ijpe.2017.10.014

Zimmermann, R., Ferreira, L. M. D. F., \& Moreira, A. C. (2020). How supply chain strategies moderate the relationship between innovation capabilities and business performance. Journal of Purchasing and Supply Management, 26(5). https://doi.org/10.1016/j.pursup.2020.100658

\section{Authors' contributions}

$1^{\text {st }}$ author: conceptualization (equal), data curation (equal), formal analysis (equal), investigation (equal), methodology (equal).

$2^{\text {nd }}$ author: conceptualization (lead), data curation (equal), formal analysis (equal), investigation (equal), methodology (equal), validation (equal).

$3^{\text {rd }}$ author: conceptualization (equal), data curation (equal), formal analysis (equal), investigation (equal), methodology (equal), validation (equal).

$4^{\text {th }}$ author: conceptualization (equal), data curation (equal), formal analysis (equal), funding acquisition (equal), investigation (equal), methodology (equal), validation (equal).

\section{Authors}

\section{Eliciane Maria Silva*}

Universidade Metodista de Piracicaba

Rodovia do Açúcar, km 156, Taquaral, 13400-911, Piracicaba, SP, Brazil

elicianems@gmail.com

https://orcid.org/0000-0002-9772-9265

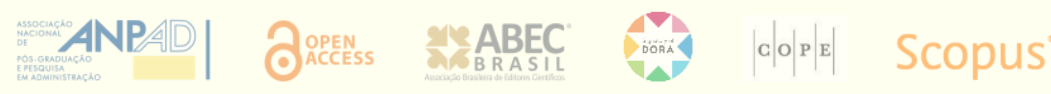




\section{Ely Laureano Paiva}

Fundação Getúlio Vargas, Escola de Administração de Empresas de São Paulo Av. Nove de Julho, n. 2029, Bela Vista, 01313-001, São Paulo, SP, Brazil ely.paiva@fgv.br

iD https://orcid.org/0000-0003-1203-0584

\section{Mário Sacomano Neto}

Universidade Federal de São Carlos Rua Sete de Setembro, n. 3148, Centro, 13560-181, São Carlos, SP, Brazil msacomano@ufscar.br (iD) https://orcid.org/0000-0002-2561-1700

\section{Kenyth Alves de Freitas}

Fundação Getúlio Vargas, Escola de Administração de Empresas de São Paulo Av. Nove de Julho, n. 2029, Bela Vista, 01313-001, São Paulo, SP, Brazil kenyth.freitas@gmail.com

(iD) https://orcid.org/0000-0002-7586-6373

* Corresponding author report of empirical data, the personal perspectives, and the use of copyrighted material.

This content was evaluated using the double-blind peer review process. The disclosure of the reviewers' information on the first page is made only after concluding the evaluation process, and with the voluntary consent of the respective reviewers. 